\section{Land use changes in suburban areas - case study of Lublin}

\author{
Mariola, Ferenc \\ Department of Rural Geography and Local Development, Institute \\ of Geography and Spatial Organization Polish Academy of \\ Sciences, Warsaw \\ mferenc@twarda.pan.pl
}

\section{SUMMARY}

The main reason to analyzing the space structure in the Lublin area is to determine the direction and pace of suburbanization in municipalities adjacent to Lublin, distinction factors and motives of population movements to the suburbs, complain rural-urban interaction and multifunctionality of land use. Housing development over the years was accompanied by confusion in planning documents and the law. Changes in regulations on land use in 1994 and 2003 in Poland additionally deepened the negative situation. Local authorities failed to control the spontaneous process of suburbanization, which adversely affected not only the spatial structure of municipalities, but also on local relationship, landscape, land use and the former urban systems. The result are long-term problems associated with incompatibility rural areas to support a growing number of residents, such as failure of the social and technical infrastructure.

Keywords: land use, suburban zone

Many definitions of the suburban zone can be found in various literature. In Poland those issues have been analyzed from the 1950s, however, they became a matter of a particular concern in the 1970s and 1980s (Bański, 2008). Dziewoński described the suburban zone as "an area in some way distinct from neighboring areas, both urban and rural". Liszewski defined it in the following way: "it is an area, where a mutual penetration of forms of life and activity, specific for both urban and rural, exist". Taking into account all the definitions of the suburban zone created over the years, one can sum it up by saying that it is a zone characterized by a lack of clear, legally defined boundaries. The size and space of the area in question are not constant - they change with the scale of the size city, its function, employment rate, a number of workplaces, the development and improvement of transportation and communication. With the development of the city, the relationships within the suburban area undergo changes connected to the functions and interdependencies enrichment, as the rural settlements transforms.

Suburban areas are connected to the concept of the urban-rural continuum. In other words, suburbs work as a transition zone between urban and rural areas. According to Sokolowski (1996), this continuum has at least three meanings. Firstly, it a process that involves the evolution of a typical rural settlement into a city. Secondly, it is a kind of a scale, where on one end we can find the typical features of rural settlements, whereas on the other one there are some distinctive characteristics of the city. Each one of the individual settlements has its own place on this scale, which depends both on the timing of the urbanization and on the urban features. The third meaning of the continuum describes it as a collection of settlements or communities that can be understood in three ways:

,a) broadly, from the rural neighborhood, through all the intermediate forms, to the urban metropolis,

b) in detail, as a central part of the scale of rusticityurbanity, where officially the rural and urban areas are not mixed,

c) even more narrowly, as a collection of settlements that do not correspond to the definitions of the city or village".

In their paper Czyż and Chojnicki (1989) recognized two approaches to the definition of the continuum. The first speaks of an extremely different units, namely the urban and the rural ones, excluding the units belonging to the continuum from being classified into either of these groups, because they have features of both urban and rural areas with varying degrees of intensity. Second approach is based on the urbanity-rusticity scale on which the settlement units are deployed (see figure 1).

Figure 1: Two approaches to the urban-rural continuum by
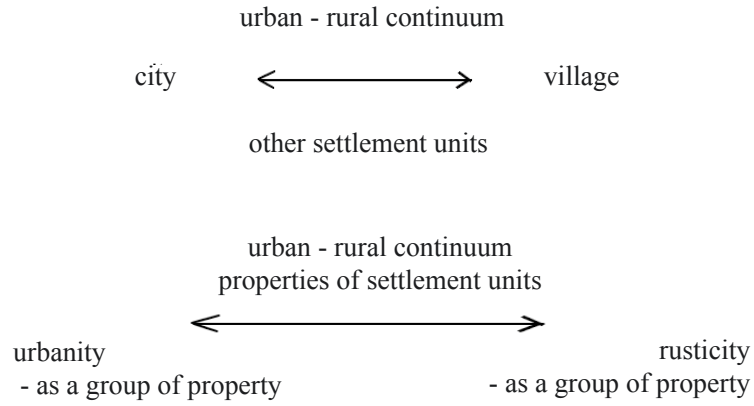

Source: Czyż and Chojnicki (1989)

According to Sokołowski (1996), the most practical approach would be to construct an intermediate model. The realities of the XXI. century have shown that there is no longer such thing as an ideal village, corresponding to its classical definition. Moreover, the city is evolving as well, so the scale of the continuum extends to the chain of settlements, each one again distinguished by a rapidly changing rate of urban features (see figure 2).

The changes that from twenty years take place in the Polish space are closely linked with the changing economy and society. The changes include the alternations in the economic structure and the nature of human activity, as well as in the age structure, professional education of the population and their expectations of their living space. The transition of the 1990s shifted the pattern of the employment of the population (see figure 3). 
Figure 2: Chain of settlements on the scale of urban-rural continuum

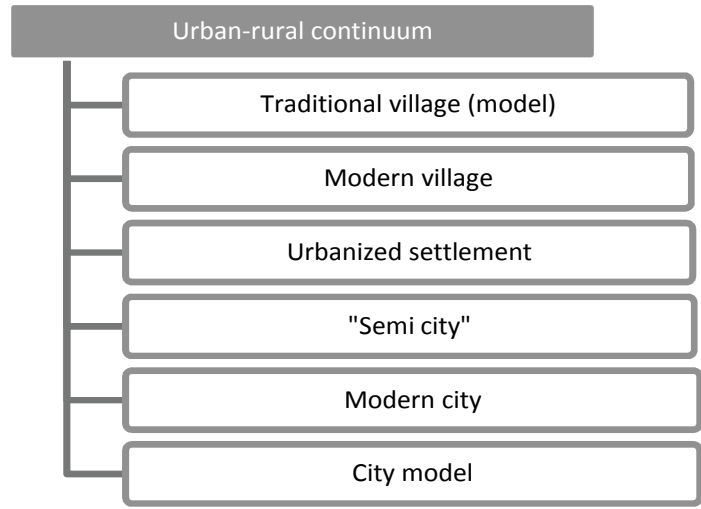

Source: Sokołowski D. (1996)

Figure 3: Structure of the employment of the population in Poland

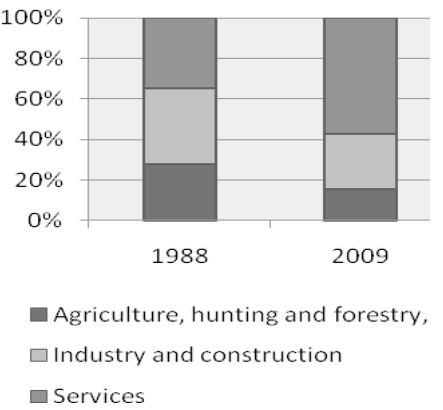

Source: based on Central Statistical Office (1989 and 2010)

Less and less people are employed in agriculture, which also has an impact on the land development. The amount of the land devoted to cultivation is decreasing, which is particularly evident in the vicinity of the cities, where new housing estates, industrial and services areas occur. In the areas on the peripheries of the regions, the land is often fallow.

A space is in demand, unfortunately it cannot be multiplied. Because there are not many possibilities of its extension, a proper disposal of the space is extremely important. Competitiveness of the space is particularly visible in the communities adjacent to large cities. In Poland, after 1989, a certain disproportions between optimal utilization of the space and the desire for economic growth could be noticed.

The main aim is to investigate the trends and factors determining changes in the suburban area on the basis of the structure of land use and the building permits issued in the municipalities adjacent to the city of Lublin (Poland). Based on previous research and observations, the following research hypotheses can be established:

1. Differences in the structure of the space between the urban and rural municipalities reduce over time.

2. Functions of urban districts and the size of the city have an impact on the changes in the suburban area.

3. Dynamics and directions of the construction development and changes in the land use are dependent on local and national politics.
To confirm those hypothesis, the author used the taxonomy of Wroclaw to analyze changes in the land use and to detect similarities in the changes directions. Additionally, the study was supported by the analysis of building permits in various places in rural municipalities adjacent to the city of Lublin. Statistical data was collected for the period 1989-2009 (see figure 4).

$$
\begin{aligned}
& \text { Figure 4: Area of research - communities adjacent to the } \\
& \text { Lublin }
\end{aligned}
$$

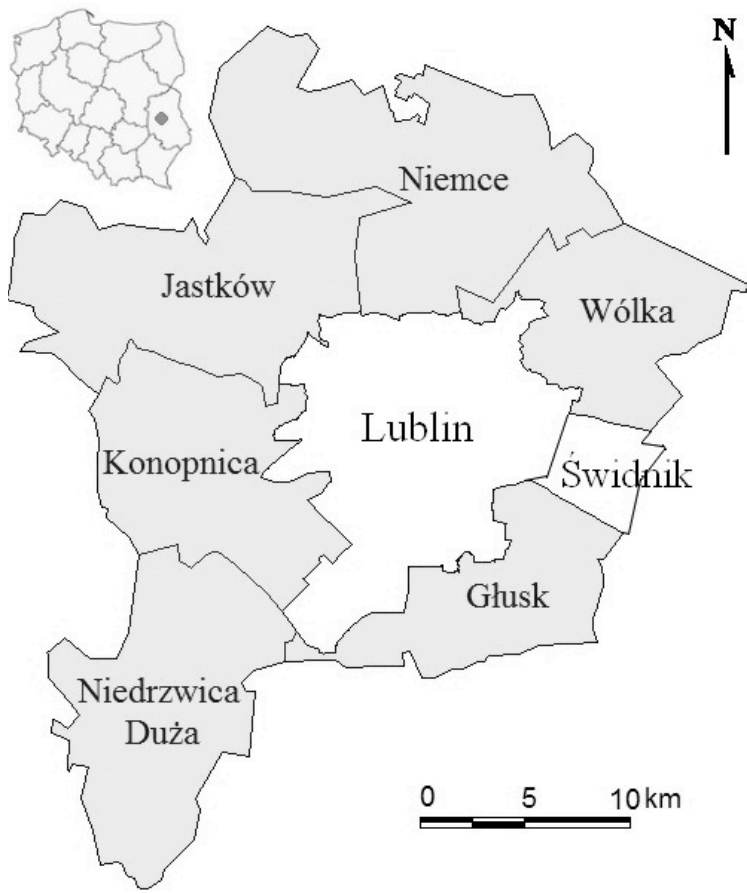

Source: own elaboration

Cluster analysis (Wroclaw's taxonomy), which was used in the analysis of the changes in the land use, was published in 1951 by the employees of the University of Wroclaw (Florek, Łukaszewicz, Perkal, Steinhaus, Zubrzycki). This method is based on constructing a dendrite, which links the most similar objects. A dendrite has the shape of an open polygonal line, with the length of its arms corresponding to the distance between objects. The appropriate sequence of actions is crucial in the construction of the model. The first step is to construct a data matrix and its standardisation. The STATISTICA program was used for this purpose. For each municipality, a percentage of the surface of the seven categories of the land use was determined, including arable land, orchards, meadows, pastures, forests and other land (waste land, water, urban areas). The examined data was taken from 1989 and 2005 (data from last census is not compatible with the data from previous years). Subsequently, using a cluster analysis, the Euclidean distance matrix was developed. The next step was to reject the identical connection, the statement of nearest unit and then placing them in the dendrite (see figure 5).

Based on the dendrograms, we see that the differences in spatial structure between rural communities between 1989 and 2005 have been increasing, while the opposite phenomenon occurs between the city of Świdnik and rural municipalities. The process of differentiation in the suburban area is visible, as each of the municipalities in 
the other degree is in the process of suburbanization. However, is a noticeable trend to not cultivate the land in all municipalities. As we can see, the changes in the land use structure became bigger between the rural and the urban municipalities.

Figure 5: Dendrites of the shortest possible connections for 1989 and 2005
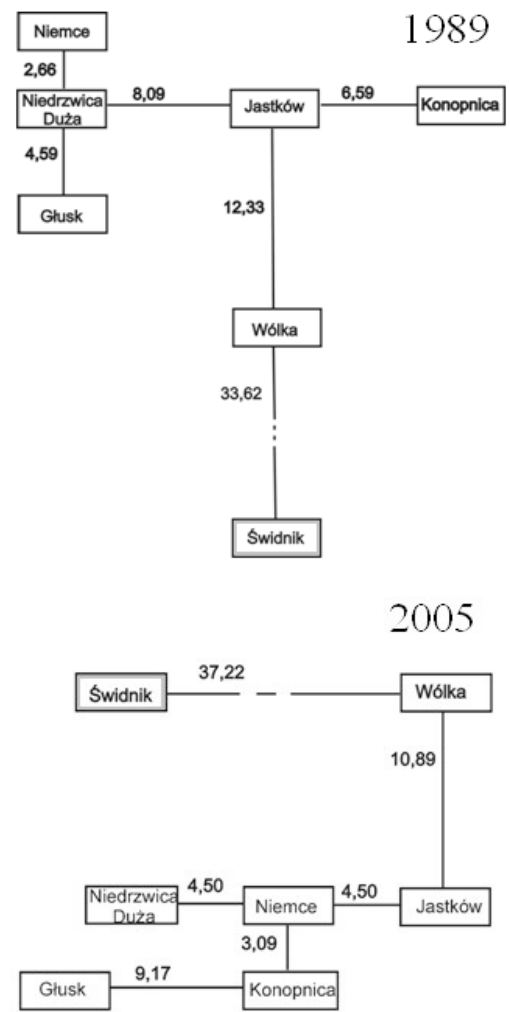

Source: own elaboration

Nevertheless, the differences between various rural communes are on the same or even lower level. The urbanization of rural communities is clearly visible, but still, the structure of the land use does not rapidly become similar to the structure of urban areas. The differences between the management of rural municipalities occur due to the internal and external conditions of those communities.

The analysis has shown that the surface of arable lands in the suburban municipalities is reduced, while the area of forests, meadows, pastures, orchards and other land increase. The largest changes occur between the surface of arable land and other areas, mainly intended for construction. In the 16 years between 1989 and 2005 , the municipalities lost about $2.5 \%$ of arable lands and gained almost as much of the other lands. In other categories the changes took place in a smaller scale. It is worth noting that in Poland, the direct subsidies to agricultural areas under cultivation were introduced in 2004. As a result, many farmers abandoned them to carry out construction projects or change the production profile.

For several years in a row, the largest subsidies by hectares were obtained from the walnut plantations, which are classified by the Central Statistical Office to the category of orchards. As expected, during the analysed period the area of orchards in most municipalities increased at the expense of meadows and pastures. The surfaces that do not require the intensive labour from the farmer, and which often produce a greater profit than arable lands have also increased. Forest areas also slightly increased, which can be linked to subsidies to the replanted land and the state policy of increasing the forest cover.

Main factors influencing the decisions of the investors are plot localisation, taxes, accessibility to town or main village and a nice landscape. During analyses of the localization of issued building permits for single family houses in rural communes adjacent to the city of Lublin in the years 1989-2009, it is visible that villages located in the nearest neighbourhood of Lublin are more popular for investors than villages localized further from the city. What is more, the villages located on crossroads and along the main routes are preferred by investors. For many years, the area on the west from Lublin was rarely chosen for house construction projects because of the localization of industrial district and a wastewater treatment plant in the eastern part of city. Thanks to the land use changes of the industrial area (resignation from the automobile industry heavily polluting the environment) and the foundation of the purification filters in the wastewater treatment plant, more and more investors applied for building permissions to build single family houses in this area (see figure 6).

Figure 6: Number of issued building permits for single family houses in rural communes adjacent to Lublin in the years 1989-2009

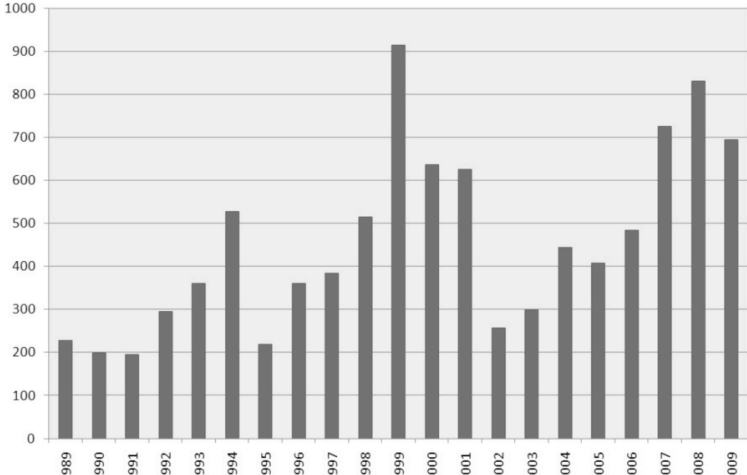

Source: own elaboration

Looking at figure 6, it can be observed that the biggest changes occurred in the periods when Poland introduced legislative changes concerning the exploitation of the space. One of the highest increases was in 1994, because from the middle of that year the Spatial Planning Law came into force.

The highest increases were registered in 1999, which is associated with the last year in which investors could apply for the construction relief. Investors who started investing in 1999 could still use it for another 3 years. This construction relief was based on the possibility of a tax deduction for 19 percent of expenditure falling within a certain amount (in 1999 up to about $6000 €$ could be recovered).

Variations in the number of permits issued in 2003 were caused by the announced changes in the building law. Investor had to submit documents proving the 
right to use the property for construction purposes in order to obtain a permit. Before the introduced changes, it was sufficient to make a statement about your right to use the property. In 2003, the number of dwellings were completed as investors accelerated the work to complete it before the implementation of the above-mentioned changes in the building laws.

It needs to be mentioned that the spatial planning in the municipalities in the area of the study as well as in the entire Poland is not satisfactory, which results in the inhibition of investment processes and deterioration in the spatial order. One of the reasons for the lack of local development plans is the reluctance of the authorities to stop issuing municipal zoning in areas that are attractive to the investors. In suburban areas arable lands change to non-arable. This occurs only in the vicinity of major urban centers, while in the case of county towns the process is stagnated.

It is worth noting that there is no overall concept of spatial development of municipalities, the existing measures are mainly based on local land use plans and studies of conditions from the 1990s. It is necessary to coordinate the plans of the cities and towns included in the suburban area.

\section{IRODALOM}

Bański, J. (2008): Strefa podmiejska - już nie miasto, jeszcze nie wieś. [In: Jezierska, A.-Kozłowski, T. L. (eds.) Gospodarka przestrzenna w strefie kontinuum miejsko-wiejskiego w Polsce.] Wydawnictwo Naukowe UMK. Torun. 29-43.

Borsa, M. (2008): Polityka przestrzenna w gospodarce regionalnej i lokalnej. [In: Strzelecki, Z. Gospodarka regionalna i lokalna.] Wydawnictwo Naukowe PWN. Warsaw. 174.

Czarnecki, A. (2009): Rola urbanizacji w wielofunkcyjnym rozwoju obszarów wiejskich. Instytut Rozwoju Wsi i Rolnictwa PAN. Warsaw.

Gorzym-Wilkowski Waldemar A. (2006): Gospodarka przestrzenna samorządu terytorialnego. Zarys. UMCS. Lublin.
Kamiński, Z. J. (ed.) (1995): Urbanizacja wsi w obrzeżach miejskowiejskich. Materiały konferencyjne. Wydział Nauk o Ziemi Uniwersytetu Śląskiego. Katowice.

Pociecha, J. (2008): Rozwój metod taksonomicznych i ich zastosowań w badaniach społeczno-ekonomicznych; http:/www.stat. gov.pl/cps/rde/xbcr/gus/POZ_Rozwoj_metod_taksonomicznych.pdf [access 20.02.2011]

Runge, J. (2006): Metody badań w geografii społeczno-ekonomicznej - elementy metodologii, wybrane narzędzia badawcze. Wydawnictwo Uniwersytetu Śląskiego. Katowice. 